\title{
Sexual Victimization of Women Police and Its Deleterious Impact on the Victims: A Thematic View
}

\author{
Ms. Laksheeta Choudhary \\ Doctoral Research Scholar \\ \& \\ Dr. Rufus D \\ Assistant Professor \\ Department of Criminology \& Police Studies \\ Sardar Patel University of Police, Security and Criminal Justice \\ Jodhpur, Rajasthan, India
}

\begin{abstract}
Sexual victimization of women prevails as a common phenomenon across the globe. It is neither limited to a specific place nor a particular profession. The police department is often represented as law enforcement agency, wherein it owes the responsibility to prevent crimes and maintain peace and harmony in society. The public point of view towards this profession is like 'Police profession is powerful'. However, in reality, the police do face many sufferings during the course in their profession. Among all problems, one issue addressed in this chapter is 'sexual victimizations of women police'. The reason being sexual victimization can destructively affect the victim's lifestyle, disturb the job efficiency and develop detachment from the workplace, which is more so in the case of women police. Hence, the present research chapter intends to understand the holistic aspects of sexual harassment of women police and its deleterious impact through thematic method of representation.
\end{abstract}

Keywords: Victims, Sexual victimization, Harassment, Impact, Women Police.

\section{Introduction}

History teaches us that numerous optimists' persistent efforts have paved way to women's educational, economic and social achievements. Nonetheless, still the risk of women's safety and security is on increasing trend. Violence against women is omnipresent. Ages have witnessed frequent victimization of women through different forms of crimes. Among those, sexual harassment at the workplace is not an uncommon victimization of women. Sexual harassment of women exists irrespective of their profession (Mahalawat \& Rufus, 2017). Moreover, the researchers have concerned that 'even women employees in the police department 
are not safe (Manickavasagam, 2016). Hence, it is a real need for the social scientists who are closely working in police related areas to examine the reality of women police safety at their profession. The police, irrespective of gender are considered to be very powerful by layman. However, women from this profession have also been witnessing sexual harassments, which are being reported sporadically. They face various forms of harassment like lewd comments, nasty body shaming, asked or forced by someone for sexual favors and being promised for some benefits (promotion, job ease, etc.). These harassments can deleteriously impact on the victim's personal/family, professional and social life. A study conducted by Burke and Mikkelsen have expressed that discrimination, sexual harassment, and inequality are the significant barriers for female police officers who seek to encounter the customary law, enforcement policies, and procedures. They also admitted that there is inadequacy of researches in such experiences of police women (Burke \& Mikkelsen, 2005). Interestingly, Hassell, Archbold \& Stichman in 2011 documented on female police officers who were continuously propositioned for sexual favors complained about their victimization. More likely, the policewomen had been victimized through sexist jokes, pornography, ridicule, and rumors. They further argued that 'sexual harassment, as a kind of discrimination, is still used to obstruct women's full integration into the police force. A study conducted by Brown et al. indicated that negative occupational culture in police are related with high prevalence of harassing incidences and discriminatory experiences of women Police (Brown et al. 2019). Moreover, in analyzing the pattern of women's contribution to Police Department Commonwealth Human Rights Initiative (CHRI) in an article, mentioned that the strength of women police in India was only 7.28 percent of the total police during the year 2017. Out of this minor women strength in police, 0.85 percent belongs to administrative ranks, 9.76 percent belongs to investigative ranks, and 89.37 percent belongs to the constabulary. These numbers are reflective of the exclusion of women in policing, especially at investigative and leadership levels. This exclusion extremely affects the quality of policing (www.humanrightsinitiative.org).

\section{Literature Review}

The brief review discussed below elucidates on the concept 'sexual harassment at workplaces', how the sexual harassments are discriminatory practices and a powerthreat at workplaces through the use of previous research findings and what are major forms of sexual harassment at workplaces.

\section{a) Sexual Harassment at Workplace: Pervasive, Discriminative \& Power Threat}

Sexual harassment is a recurring problem around the globe (Hejase, 2015). It is pervasive and an umbrella concept. In India, legally the Sexual harassment is defined as follows: 'sexual harassment includes any one or more of the following 
unwelcome acts or behavior (whether directly or by implication) namely: i) physical contact and advances or ii) a demand or request for sexual favours or iii) making sexually coloured remarks or iv) showing pornography or v) any other unwelcome physical, verbal or non-verbal conduct of sexual nature' (The Sexual Harassment of Women at Workplace (Prevention, Prohibition \& Redressal Act, 2013)).

Crosthwaite and Priest expressed the definition of sexual harassment, wherein they described harassment as a pervasive feature of the society that occurs in both public and private life. They further stated that harassment is different in the role it plays in social interactions and its phenomenology for the victims experiencing harassment (Crosthwaite \& Priest, 1996). Also, Brown defines the discriminatory treatment in terms of limited job-related opportunities with limited access of women officers to higher rank \& specialist roles and exposure to sexual harassment. Brown's survey conducted among British police forces confirmed widespread exposure to harassment and other discriminatory treatment forms (Brown, 1998). Yet another study conducted by Suresh, Sridhar and Kairanna in 2014 described the sexual harassment at organization as a form of destructive workplace communication that has damaging and devastating effects, wherein it deleteriously affects victims and organizations on the whole.

The continuing violence against women is an indication of gender discriminatory behaviors indoctrinated in the society. Moreover, the harassment may take the form of words, gestures or actions, which tend to annoy, alarm, abuse, demean, intimidate, belittle, humiliate or embarrass another or create an intimidating, hostile or offensive work environment (Unnikrishnan et al. 2010). This is supported by the study conducted by Steinporsdottir and Petursdottir among Icelandic police force in which they have concluded that incidences both bullying and sexual harassment are more frequent against women police by the male perpetrators. Accordingly, perpetrating of these incidences are the conscious or unconscious methods of maintaining the gender hierarchy in the police force (Steinporsdottir \& Petursdottir, 2018). Also, a research article on 'Sexual Harassment, Workplace Authority, and the Paradox of Power' that relates power and harassment identified that women at power are more likely to experience harassing incidences, particularly in maledominated work settings. Popular characterizations portray male supervisors harassing female subordinates; Contradictory to it, the power-threat theories suppose that women in authority may be more frequent targets of harassment (Mclaughlin, Uggen \& Blackstone, 2012).

These aforementioned research findings have strongly indicated us with a message that even working women in the police departments have the proximity of getting victimized irrespective of administrative position they hold. 


\section{b) Types of Sexual Harassment}

EEOC's (The U.S. Equal Employment Opportunity Commission) 'Policy Guidance on Current Issues of Sexual Harassment' mentioned that there are two major types of Sexual harassment (www.eeoc.gov/laws/guidance). These are pervasive forms of harassment existing in one or the other form. The nature and extent of harassment may vary from one place or profession to another.

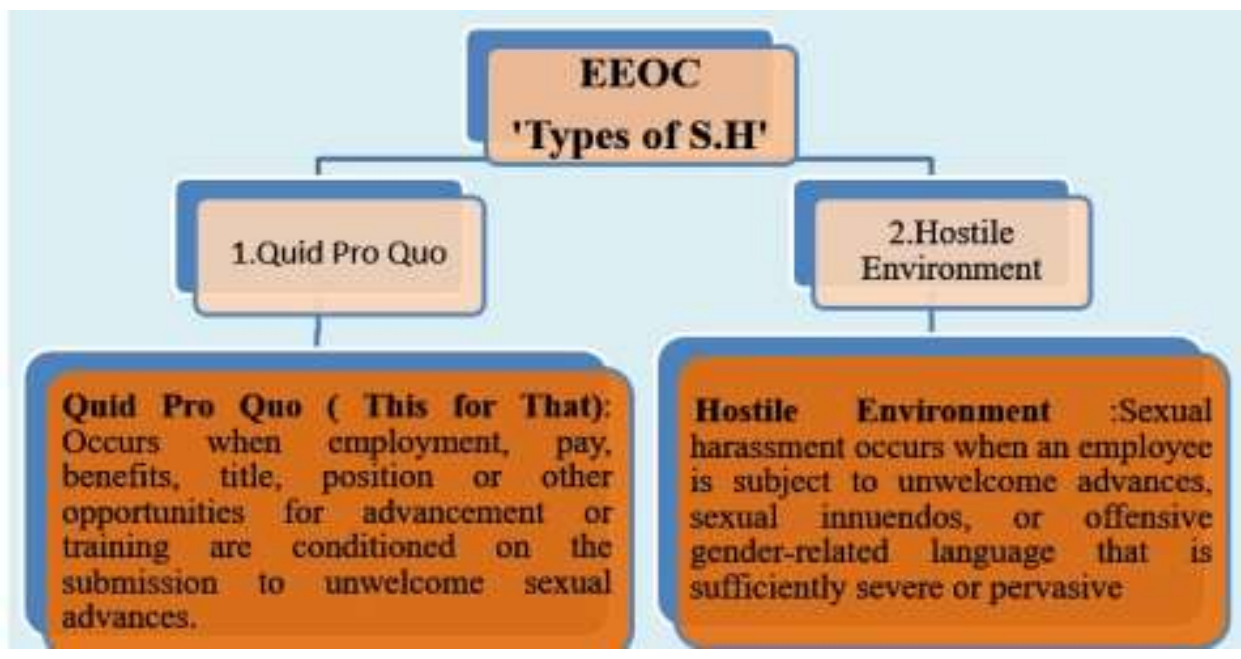

Fig.1: Two Major Types of Sexual Harassments at Workplaces

Haas, Timmerman and Hoing in their research on sexual harassment among Dutch police officers have pointed out that 'sexual harassment prevails in the police force' as like as in many male-dominated organizations. They also cited that 77percent of police officers from thirty-five countries have experienced sexual harassment from colleagues. They asserted that three forms of sexual harassment exist in the workplace. Firstly, gender harassment -nonsexual; Secondly, unwanted sexual attention, uninvited sexual comments or gestures; and thirdly, sexual coercion, which involves work-related intimidation or rewards used to attain sex (Haas, Timmerman \& Hoing, 2009). In USA, the results of a mixed-method approach study entitled 'Sexual Harassment in Law Enforcement: Incidence, Impact, and Perception' found that most respondents experienced sexually harassmentbehaviors. The incidences reported were very few, but retaliation was frequent and often severe. Regression analyses demonstrated that harassment negatively affected the victim's personal and professional life. However, the narrative responses revealed that respondents did not typically appraise them negatively (Lonsway, Paynich \& Hall, 2013). Thus, the researchers identified more forms of sexual harassment of women police. It is important to note that among them the most common are sexual joking and sexual remarks (Somvadee \& Morash, 2008), advanced by sexual favours (Bhat \& Deshpande, 2017), sexism, skewed physical 
fitness criticism (Muhlhausen, 2019), bullying (Collin, 2004; Steinporsdottir \& Petursdottir, 2018), forcing to quid-pro-quo, sexually coloured humours, namecalling, etc.

\section{Objectives}

To understand the nature and possibility of reasons, which are directly or indirectly responsible for sexual harassment of police women in their profession

$>$ To analyze the ill-impacts of sexual harassment victims and understand the reasons for non-reporting of harassment victimization

\section{Methodology}

The present chapter uses thematic representation about the sexual harassment of women police and its deleterious impact on the victims through descriptive research design. The thematic based understanding on the related themes has been further theoretically analyzed and interpreted by the authors of the article.

\section{a) Data Sources}

The entire study is based on secondary sources, wherein data have been in accordance with objectives, which included research articles, news items, books, online sources, etc.

\section{b) Limitations}

i) The chapter is not very specific in Indian context; as limited research resources are available in this particular study theme.

ii) Though 'sexual harassment of women police' is the major theme of the chapter, but authors used few findings from studies of sexual harassment at other workplaces too, for better understanding deleterious impacts of the problem, non-reporting behavior of victims, etc.

\section{Sexual Victimization of Women Police}

It has been observed that scarcity of literature is there in this present theme related to women police. However, the available studies have proved its existence in the domain of police profession. Hence, study's thematic view included understanding the nature of sexual harassment, sharing of few incidences of sexual harassment, common causes connected with sexual harassment, reasons for non-reporting of victims of sexual harassment and deleterious effects or impact of sexual harassment on its victims with regard to women police. Furthermore, common studies on sexual 
harassments have also been cited, the reason being it is inevitable to show the nature, causes and impact of sexual harassment at any workplaces.

\section{a) Nature of Sexual Victimization of Women in Police Profession}

It is understood through the related studies that a working woman who goes through the events of sexual victimization is extremely painful and utter annoyance to her physical, mental, career and social health. The similar deleterious effects happen with victims of sexual harassment, who are doing service in police profession. Also, a research study found that harassment at workplace has become a matter of great concern in all sectors of economy due to the fact that it showed various negative consequences. The women respondents from different workplaces like banks, educational institutions, hospitals, and shops were studied. Nearly, 50 percent of respondents got victimized within one year of joining their employment. The study also revealed that work experience and frequency of facing harassments were inversely related. The most common type of harassment faced was (67.4 percent) and this followed by physical (23.9 percent) in nature (Unnikrishnan et al. 2010). Also, while comparing harassment faced by women and men in law enforcement agencies of Florida, it has been found that women police experience a greater extent of sexual harassment and bullying than men. The evidences of increase in sexual harassment of female police officers made to believe that 'sexual harassment in policing is a national problem (Collin, 2004). Similarly, another survey conducted in Norway among 766 police officers in which females are provided significantly lower level of opportunities. Also, they faced discrimination and sexual victimization more than male officers (Burke \& Mikkelsen, 2005).

Seklecki and Paynich in 2007 conducted a U.S. based survey among female police officers. The study found that 27.1percent of respondents reported experiences of sexual harassment. Victims experienced harassment incidences both by the citizens and their department staffs. Forms of harassment were: Insulations, name-calling as homosexuals by citizens, sexually explicit remarks, dirty jokes, etc. Some respondents accepted that sexually colored humor was prevailing within their department. A portion of participants expressed that they had no plans to leave the profession due to the prevalence of sexual harassment (Wilson, 2016). Yet another study conducted by Mahalawat and Rufus in 2017 on a sample size of one hundred women police in Jaipur, Rajasthan. The findings revealed that nearly 26 percent of women police have faced sexual harassment by both the male counter parts and society members during social interactions related to their profession. The study showed that mostly the harassers were from public. Also, verbal abuse by using dirty languages, threatening the women police, interference and dominance by political \& local leaders', passing disrespectful comments such as women police are incapable of handling emergencies and attempts to offer a bribe to police in return asking for favors were some of the forms of harassment mentioned in the study. 
A study conducted on female police officers in California by Brodeur identified that every law enforcement woman had experienced environmental harassment. Moreover, hostility has been commonly experienced than sexual harassment. The female police officers also reported that: 'gender-related jokes are part of the policing culture; and that female officers were negatively targeted because of their sex' (Brodeur, 2018). A report by Muhlhausen in 2019 regarding the status of researches on women in American policing revealed that many female police did not express that they experienced sexual harassment. However, women in police reported that specific behaviors experienced by them would really constitute harassment. They also reported about their experiences in connection with adverse or hostile environments, sexism, skewed physical fitness assessments, double standards, boys club and lack of support \& opportunity during their career. An online survey by Brown, Gouseti and Fife-Shaw on police staff serving in England, Wales and Scotland found that majority of harassment incidences (around 75 percent) were associated with sexual banter apart from exposure to severe types of harassment (Brown, Gouseti \& Fife-Schaw, 2017). Many studies revealed the existence of varied forms of harassment in different professions, including law enforcement agencies. Mainly, women are targets of sexual victimization at workplaces compared to their male co-workers.

\section{b) Incidences of Sexual Victimization of Women Police}

As per a news-item published in The Times of India (13 September 2016), 24 women cops have accused an inspector level officer in Delhi police have involved in sexual harassment at workplace. The allegation on him was that he had commented on female colleagues' clothes, and skin color. Interestingly, one-woman police constable has alleged of being harassed, ever since she rebuffed the man's overtures and complained against him to higher authorities. The accused had allegedly remarked on her attires, skin color and called her alone to his office. Also, reported that due to impact of his periodical harassment activities, she was so depressed and expressed to commit suicide. The complaints by remaining 23 women police personnel accused the same perpetrator mocking their skin color and gesture. The victims revealed that the accused boasted and threatened them for not making any complaint to higher officials. Victims also alleged that his subordinate was also involved with him. The victimization lasted for approximately four months, even after the inquiry was initiated (Bhattacharya, 2016).

Surprisingly, a finding indicated that 13 women from USA have sued their law enforcement agencies either for sexual harassment or kind of sexual discrimination. The information was about types of sex discrimination that women experienced in law enforcement. They faced ill-treatment stretching from generalized incivility to sexual-harassment. They became victims of sex discrimination, including being passed over for promotion, unfairly disciplined, and even termination. Particularly, four women of law enforcement have experienced forceful attempts to engage in 
sexual activity. Some of them were physically threatened during both before and after filing a complaint. The highlights with regard to consequences of complaint are such as, when the victims raised their voice for justice and filed complaint, they faced retaliation, social isolation, negative job consequences and vandalism to their property. Also, faced even more severe behaviors such as death threats and failure to provide backup in emergencies, wherein the supervisors and coworkers behaved ambiguously, people have ignored the victims, false rumors or lies being spread and some people even refused to work with them. This attitude sometimes extended to family. Almost half of the women left agencies they had sued and most left law enforcement field entirely. On the whole, such experience negative workplace behaviors harmfully impacted on victims' psychological, physical and police professional well-being (Lonsway \& Alipio, 2007). A study conducted by Flynn indicated that Philadelphia police department chief inspector one among the highest-ranking commanders in the department has been arrested and charged with allegation of sexual assaults of three subordinate officers. It has been reported that when two junior officers came to chief inspector seeking guidance, both women ended up being sexually assaulted by him. In the third case, the harasser invited a female officer to join his elite task force and after three days of her joining she was forcibly kissed, groped and digitally penetrated by him. It is after the female officers complained, they allegedly faced retaliation. The chief's arrest follows a long line of grievances from female officers, wherein two of the alleged victims have publicly accused him of his sexual assault in news articles and later he was suspended (Flynn, 2019).

The Tamil Nadu woman cop lodges sexual harassment against top officer - a news item in India Today has been published (22 August 2018). In an alleged complaint, a woman Superintendent of Police (SP) who had worked in Directorate of Vigilance and Anti-Corruption (DVAC) accused her senior officer who was in the rank of IGP of sexual harassment in her complaint. She had been subjected to sexual harassment for around seven months by the senior officer who allegedly tried to molest her. In August 2019, the case was transferred from Tamil Nadu to Telangana. The direction of transferring the case was based on woman officer's plea that the officer behind the harassment was influencing the Internal Complaints Committee (ICC). Later, after specific procedures, he was transferred to the Economic Offences Wing (Vasudevan, 2018). Another news article in The New Indian Express (9 January 2020) reported another incidence of women cop in the rank of constable claiming sexual harassment against seniors. This news has been posted in Lucknow and alleged harassment by her seniors, wherein she reported through video clips posted on social media regarding the same. She expressed sadness that "when she is not safe, how could she assure any other person's safety?" she added that when she is a victim and did not get justice, how can she help deliver justice for another person? The complaint was not registered until the video clips went on viral. After the video clip went on social media, the investigation got initiated. 


\section{c) Reasons behind the Occurrence of Sexual Harassment Incidences at Workplace}

The Role Theory stresses on onset of normative expectations that are presumed to define particular positions or statuses in social structure and their corresponding roles or behaviors in interaction with others. The role theory may sometimes become a conflict and a source for initiating some form of harassments as some people cannot accept the role of women in household chores. They assume that women are captive of household works and males are supposed to move outside the home and earn. These conflicting negative attitudes of some people may serve as a cause of sexual harassment of women at their profession. Likewise, women police recruited at subordinate positions can be linked to the status conflict that directly or indirectly may lead to sexual victimization of them (Garcia, 2003). The sexual harassment expressed as a visible example that multitudes of workplace disputes and processes to resolve disputes. The individual, occupational and organizationallevel variables all influence the origins of sexual harassment (Lach \& Patricia, 1993)

The causes of harassment may occur at various levels. At the individual level, the personalities of the harasser and the harassed may be factors; At the dyadic level, when two people conflict; At the group level, where psycho-social dynamics is a factor; and finally at the organizational and societal levels, where it is a matter of culture and ideology (Hoel \& Cooper, 2000; Lutgen-Sandvik, Namie \& Namie, 2009; Bourgeois, Ohana \& Renault, 2016).

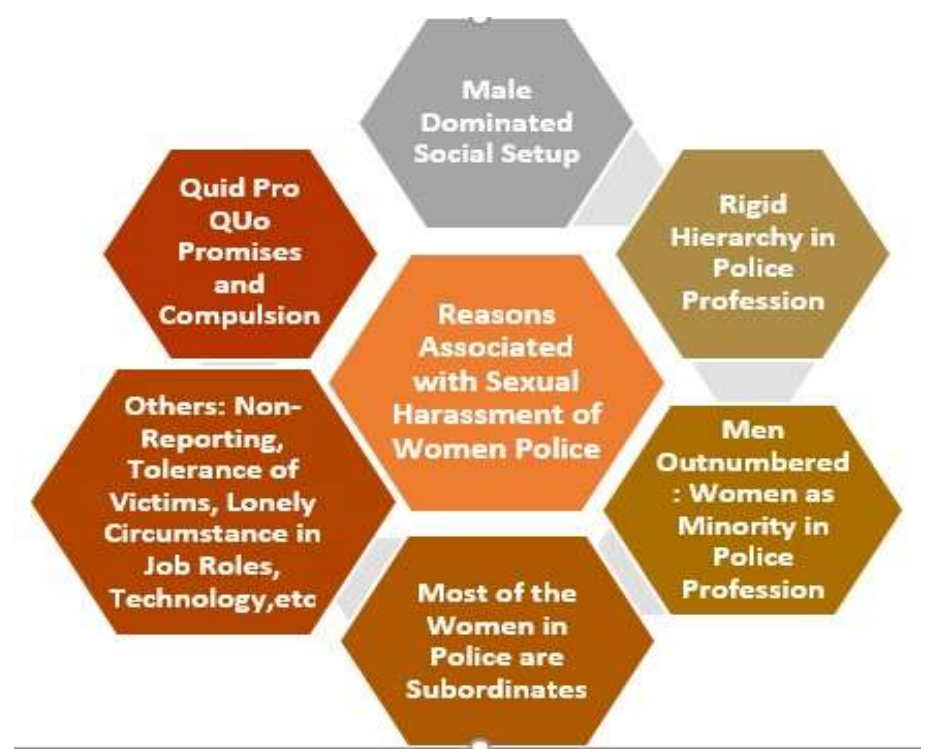

Fig.2: Reasons Associated with Sexual Harassment of Women Police

Source: Compilation of Secondary Data 
Organizational climate is a strong predictor of workplace sexual harassment. The two characters 'men outnumbering women' and 'hierarchical power dynamics' are absolute facts in police organizations at national and global levels. Thus, these characters can contribute to the prevalence of sexual harassment in police organizations, if appropriate preventive measures are not taken. Even the hierarchical power dynamics it is considered to be the root of sexual harassment (Science News, 2017).

Women in Indian police contribute only a meager (8.98 percent) portion (Press Information Bureau (PIB), 2020), wherein nearly 9 out of 10 women in the police force are at constabulary level (cnbctv18.com). Bhat and Deshpande 2017 mentioned the male-dominated organizational setup: the place where harassment occurs to show male folk domination. The inferior job position of women may serve sexual harassment as one mode asserting control over powerless and misperceptions about friendly nature of a woman. Women with higher academic profiles and lesser job opportunities are harassed and advanced by sexual favors by the person in charges; in return, they promise women certain benefits. This is supported by a study conducted by Barak focusing on online sexual harassment, which indicated that sexual harassment behavior occurs as a product of person and situation characteristics with substantial personal and organizational costs. Moreover, technology continues to provide new methods and venues for harassment such as cell phones, video games, the internet, untraceable message services (Barak, 2005).

\section{d) Reasons for Non-Reporting of Sexual Harassment Victimizations}

Johnson, Kirk and Keplinger in 2016 mentioned reasons for non-reporting of victimization are mainly due to: i) organizations act of trivializing it ii) reporting of victimization results in hostility and retaliation against the victims iii) another reason is the bystander effect, which says that we are less likely to help victims when others are present and iv) bystander effect occurs for two reasons: a) diffusion of responsibility (if others are present, someone feels that other people present are responsible for intervening) and b) social influence (bystanders observe others' behavior to determine the correct behavior; so if no one is intervening then that seems to be the correct behavior, as people abide by the status quo). Also, victims hesitate to objectively indicate about the harassing incident due to fear of adverse career consequences of losing the job and facing further ramifications (Shetty \& Nithyashree, 2017; Vijayasiri, 2008; Brodeur, 2018). The threats to self-esteem, risk of secondary victimization, women fear facing doubts, scrutiny and victim-blaming. These fears are captured by stigma theory, which suggests that individuals will avoid sharing a stigma because of self-blame, shame, and fear of negative judgments from others. Moreover, societal stigmatization can also adversely affect the self-esteem of an individual (Keplinger et al. 2019; Choudhary \& Rufus, 2019a). 
The report of National Center for Women and Policing (NCWP) cited the sluggishness and inadequacy in handling sexual harassment complaints, lack of training of authorities to handle sexual harassment cases and chauvinistic social system followed by the police administrators were the reason for non-reporting or less reporting of sexual victimization by women police officers (Wilson, 2016). A case study of an elite military institution mentioned that the 'perception that nothing will happen' and the 'possibility of negative repercussions', including social ostracism and retaliation, were the reasons for preventing women from reporting harassing episodes (Pershing, 2003). Another workplace harassment study on student respondents reported their experience in the institution, wherein they indicated the reasons for non-reporting of the harassment were not knowing where to report it, fighting the problem themselves, wish of harassed not to report it and thinking reporting it will not make a difference (Jussen et al. 2019; Choudhary \& Rufus, 2019a; Choudhary \& Rufus, 2019b).

\section{e) Deleterious Impacts of Sexual Victimization on Its victims}

Sexual harassment of females in any profession or organization decreases organizational productivity and significantly produces deleterious impact to working women (Hassell, Archbold \& Stichman, 2011). Especially, sexual harassment prevails in the law enforcement profession, where officials have long working hours and risk-taking tasks. In such situations, it will severely impact the health of individual victims and organizational cooperation. Furthermore, sexual victimization will surely reduce job satisfaction and will lead to detachment from the job, wherein sexual harassment as an issue that affects employee effectiveness. The harassment affects the victim, but it also affects fellow employees, the organizational management, and even the harasser, leading to less productiveness (Wright \& Bean, 1993). Many studies had confirmed the existence of ill consequences of one or the other form of sexual harassment in different professions, including the law enforcement agencies. Also, a study pointed that some of the ill consequences faced by female victims of sexual abuse causing deleterious effects are cognitive deficits, asymmetrical stress responses, illnesses, persistent posttraumatic stress disorder, physical and sexual re-victimization, drug and alcohol abuse, and sometimes domestic violence (Trickett, Noll \& Putnam, 2011). 


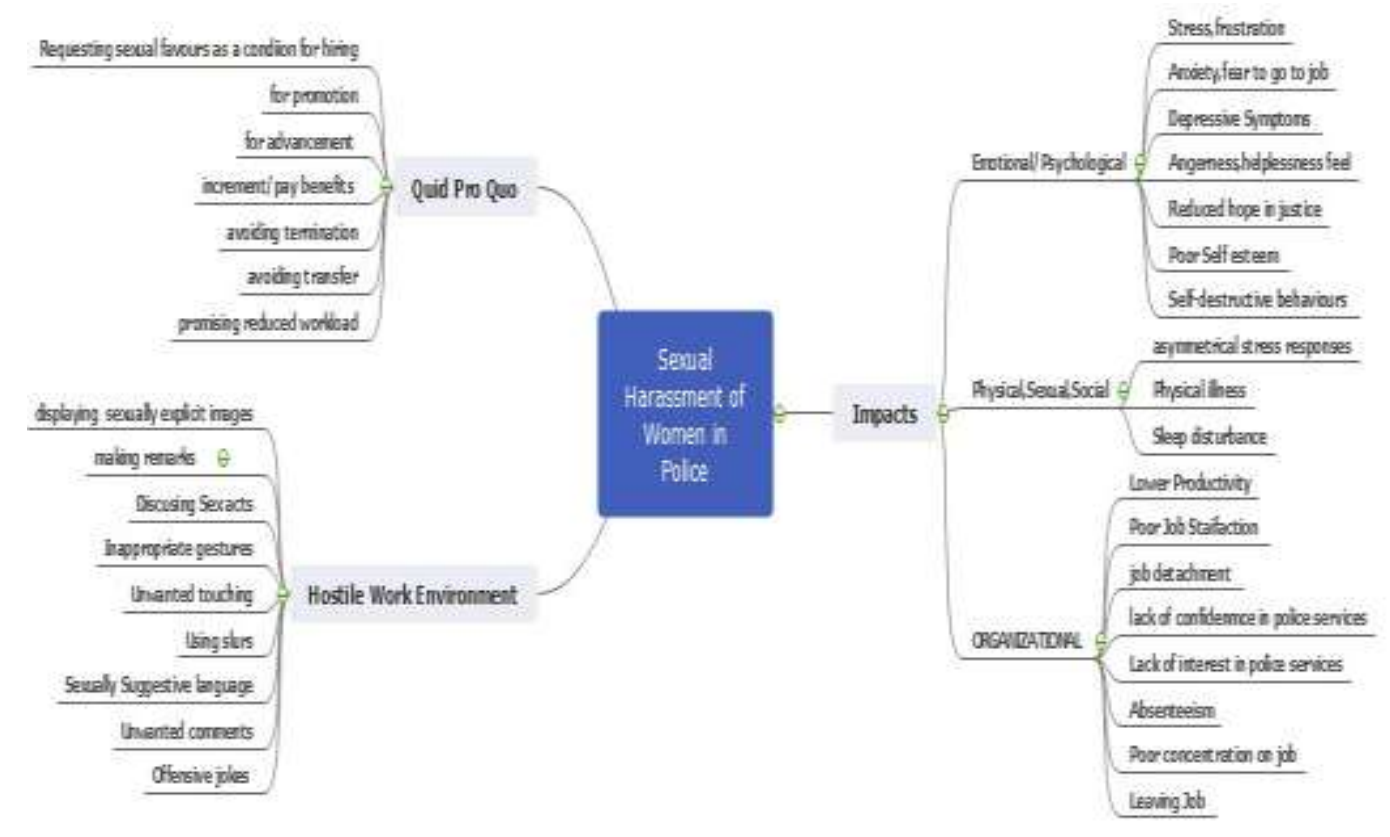

Fig. 3: Thematic View of Sexual Harassment of Women in Police and its Impact on Victims

Source: Compilation of Secondary Data

A self-administered anonymous survey conducted by Krimmel and Gormley among women law enforcement officers from New Jersey and Pennsylvania using job satisfaction scales found that job satisfaction levels were correlated with the proportion of women in their respective departments. Women who made less than 15 percent of their department experienced less job satisfaction. They experienced job-related depression and lower self-esteem than those women working in departments where the number of women outnumbers men. It is noteworthy to mention that literature conveyed that women are vulnerable to face sexual harassment, if their numbers are significantly less than male coworkers. This fact can be corroborated with the existing lesser strength and sub-ordinate position of women in police, specifically in India, and generally in the world (Krimmel \& Gormley, 2003). Also, Friborg et al. in their study underlined the importance of investigating sexual harassment from clients or customers and sexual harassment by colleagues, supervisors, and subordinates. They also found employees harassed by colleagues, supervisors, or subordinates who had higher depressive symptoms than employees harassed by clients or customers (Friborg et al. 2017).

A study conducted on 4296 representative samples, including Dutch Policemen and Policewomen found that women were more bothered by sexual harassment than men. Also, victims who were bothered by harassing behaviors faced more health- 
related problems than those who were unbothered (Haas, Timmerman \& Hoing, 2009). A comparative study on 'The impact of sexual harassment on job satisfaction, turnover intentions, and absenteeism' from Pakistan and United States found that Pakistani employees who victims had greater job dissatisfaction and higher overall absenteeism than their U.S. counterparts (Merkin \& Shah, 2014). Also, Gale et al. in their study among U.S. and Canada-based participants $(4,459)$ from the Harvard Flight Attendant found that Depression, Sleep disturbances, fatigue, and musculoskeletal injuries were the adverse effects of workplace harassments (Gale et al. 2019). Another study by Vargas et al. examined incidences and Impacts of Sexual Harassment of Physicians and other Faculty at an Academic Medical Center. The study revealed that increased harassment experiences were independently associated with lower mental health, job satisfaction, a sense of safety at work, and increased turnover intentions, with no significant interactions by gender (Vargas et al. 2020). Another study entitled Sexual Harassment in Law Enforcement Incidence, Impact, and Perception found that general job stress, frustration, trauma outside of the workplace, were the ill effects of harassment (Lonsway, Paynich \& Hall, 2013). Also, detachment from the job or quitting the job was another negative organizational effect (Doss, Mukherjee \& Kumar, 2014). Generally, studies have opined that when women victims neglect the incidences of sexual victimization which may lead to future severe adverse impact of victimization (Choudhary \& Rufus, 2019a; Herbenick et al. 2019; Choudhary \& Rufus, 2019b).

\section{Suggestions}

The following suggestions are not limited to dealing with the issues of sexual harassment of women in police:

$>$ A secret anonymous vigilant committee shall be framed to actively supervise every kind of harassment activity occurring at workplaces or in the police profession, even though systems like Internal Complaints Committee (ICC) is present. The committee should comprise of dedicated both male and female police officials.

$>$ A separate women cell must be made for discussing every aspect of workplace threat to women safety. The complete anonymity of victim should be maintained and after a keen watch, necessary action should be recommended and taken if harassment persists.

> In India, the National Crime Records Bureau's report on 'Crime in India' may also receive such separate data of sexual harassment of women in CJS, include and publish under a column of crimes against police. Likewise, other countries shall follow this method for maintaining such reports.

$>$ The conduct scientific researches on this subject by criminologists and other social scientist are the need of the hour to prevent sexual harassment of women 
police. On the other hand, access of primary and secondary information for criminologists and social scientists related to police, prison and victims from government authorities should be made available for studies, which could highlight the situations and create enough awareness with regard to harassment for overall welfare of the society. Moreover, the co-operation of police heads is very much essential for such researches, provided the privacy and confidentiality of the participants to be ensured.

$>$ Regular programs on gender sensitization should be given to police in all levels.

$>$ Women in police should be encouraged to give voices against such sexual victimization that happens within and outside their workplaces.

$>$ The punishment for disrupting the workplace environment by causing sexual harassment against women police should be made swift and strict in police profession in addition to legal punishments.

\section{Conclusion}

Sexual victimization especially harassment, with regard to women is pervasive. The available literature had confirmed various forms of harassment episodes persisting in different fields and professions. The present chapter is not meant to find out lacuna or blame the law enforcement agencies. Instead, the researchers carefully intend to figure out and conceptually emphasized on various harassments experienced by women police and at present at their workplaces. Also, indicated that existence of such harassment against women due to some perpetrators would result in devastating and deleterious impacts on the victims. Unfortunately, among other common reasons, women in police may avoid or struggle to open up their voices against them due to rigid hierarchical system and fear connected with that. Furthermore, the non-reporting of incidents due to various reasons poses a challenge and threat to workplace environment of women police. These harassing episodes have harmful and negative consequences in varied areas of victims' life. Apart from professional life, it destructively impacts on personal and social life of a victim. The sheer necessity of the moment is to understand the nature and magnitude of sexual victimization of women in police and also to ensure safety and utmost security in their workplaces.

\section{References}

Barak, A. (2005). Sexual Harassment on the Internet, Social Science Computer Review, Vol.25, No.1, pp.77-92.

Bhat, R. A. \& Deshpande, A. (2017). An Overview of Sexual Harassment of Women at Workplace in India: An Analytical Study, International Journal of Innovative Research in Science, Engineering and Technology, Vol.6, No.7, pp.14361-14369. 
Bhattacharya, S. (2016). 24 Delhi policewomen Accuse Cop of Harassment, $13^{\text {th }}$ September 2016, The Times of India.

Bourgeois, C., Ohana, M. \& Renault, S. (2016). Organizational Factors in Harassment: Is the Employer Responsible? The Case of France, Recherches en Sciences de Gestion, Vol.112, No.1, pp.103-120.

Brodeur, V. (2018). Female Law Enforcement Officer's Experiences of Workplace Harassment, Electronic Theses, Projects and Dissertations, California State University, San Bernardino, pp.1-133.

Brown, J. M. (1998). Aspects of Discriminatory Treatment of Women Police Officers Serving in Forces in England and Wales, British Journal of Criminology, Vol.38, No.2, pp.265-282.

Brown, J., Fleming, J., Silvestri, M., Linton, K. \& Gouseti, I. (2019). Implications of Police Occupational Culture in Discriminatory Experiences of Senior Women in Police Forces in England and Wales, Policing and Society, Vol.29, No.2, pp.121-136.

Brown, J., Gouseti, I. \& Fife-Schaw, C. (2017). Sexual Harassment Experienced by Police Staff Serving in England, Wales and Scotland: A Descriptive Exploration of Incidence, Antecedents and Harm, The Police Journal: Theory, Practice and Principles, Vol.91, No.4, pp.356-374.

Burke, R. J. \& Mikkelsen, A. (2005). Gender Issues in Policing: Do They Matter? Women in Management Review, Vol.20, No.2, pp.133-143.

Choudhary, L. \& Rufus, D. (2019a). Magnitude of Eve-Teasing: A Victimological Assessment among Girls in Higher Education Institutions with Special Reference to Jaipur and Jodhpur, In: Ganesan, R., Bharathi, G. V., Anila, S. \& Kumudha, R. (Eds.), Women Empowerment: Leadership \& SocioCultural Dimensions, Bonfring, Coimbatore, pp.144-173.

Choudhary, L. \& Rufus, D. (2019b). Sexual Harassment in Public Transportation Buses: A Survey on Experiences and Safety Perceptions Among Female Students of Colleges in Jodhpur District, In: Shekhar, B. (Eds.), Criminology and Victimology Through the Looking Glass, Manonmaniam Sundaranar University Publication, Tirunelveli, pp.72-93.

Collin, S. C. (2004). Sexual Harassment and Police Discipline, Policing: An International Journal of Police Strategies \& Management, Vol.27, No.4, pp.512-538. 
Crosthwaite, J. \& Priest, G. (1996). The Definition of Sexual Harassment, Australasian Journal of Philosophy, Vol.74, No.1, pp.66-82.

Doss, E. N., Mukherjee, P. K. \& Kumar, M. A. (2014). A Study on Sexual Harassment Among Women Workers at Work Place In Vellore, Indian Journal of Applied Research, Vol.12, No.4, pp.35-37.

Flynn, M. (2019). Sickening: Top Philly Cop Charged with Sexually Assaulting Officers He Mentored, The Washington Post, $25^{\text {th }}$ October 2019.

Friborg, M. K., Hansen, J. V., Aldrich, P. T., Folker, A. P., Kijaer, S., Nielsen, M. B. D., Rugulies, R. \& Madsen, I. E. H. (2017). Workplace Sexual Harassment and Depressive Symptoms: A Cross-Sectional Multilevel Analysis Comparing Harassment from Clients or Customers to Harassment from other Employees amongst 7603 Danish Employees from 1041 Organizations, BMC Public Health, Vol.17, No.1, pp.675-686.

Gale, S., Mordukhovich, I., Newlan, S. \& Mcneely, E. (2019). The Impact of Workplace Harassment on Health in a Working Cohort. Frontiers in Psychology, Vol.10. No.1181, pp.1-10.

Garcia, V. (2003). Difference in the Police Department, Journal of Contemporary Criminal Justice, Vol.19, No.3, pp.330-344.

Haas, S. D., Timmerman, G., \& Hoing, M. (2009). Sexual Harassment and Health among Male and Female Police Officers, Journal of Occupational Health Psychology, Vol.14, No.4, pp.390-401.

Hassell, K. D., Archbold, C. A. \& Stichman, A. J. (2011). Comparing the Workplace Experiences of Male and Female Police Officers: Examining Workplace Problems, Stress, Job Satisfaction and Consideration of Career Change, International Journal of Police Science and Management, Vol.13 No.1, pp.37-53.

Hejase, H. J. (2015). Sexual Harassment in the Workplace: An Exploratory Study from Lebanon, Journal of Management Research, Vol.7, No.1, pp.107-121.

Herbenick, D., van Anders, S. M., Brotto, L. A., Chivers, M. L., Wessel, S. J. \& Galarza, J. (2019). Sexual Harassment in the Field of Sexuality Research, Archives of Sexual Behavior, Vol.48, pp.997-1006.

Hoel, H. \& Cooper, C. (2000). Destructive Conflict and Bullying At Work, Manchester School of Management, University of Manchester Institute of Science \& Technology (UMIST), United Kingdom, pp.1-30. 
Indian Constitutional Act. (2013). Article 14, 15 \& 21, Constitution of India, The Sexual Harassment of Women at Workplace (Prevention, Prohibition and Redressal) Act No.14, 2013, Ministry of Law and Justice, Government of India.

Johnson, S. K., Kirk, J. F. \& Keplinger, K. (2016). Why We Fail to Report Sexual Harassment, Havard Business Review, $4^{\text {th }}$ October 2016.

Jussen, L., Lagro-Janssen, T., Leenders, J., Logie, C. \& Mijdam, R. (2019). Underreported and Unknown Student Harassment at the Faculty of Science, Plos One, Vol.14, No.4, pp.1-10.

Keplinger, K., Johnson, S. K., Kirk, J. F. \& Barnes, L. Y. (2019). Women at Work: Changes in Sexual Harassment between September 2016 and September 2018, Plos One, Vol.14, No.7, pp.1-20.

Krimmel, J. T. \& Gormley, P. E. (2003). Tokenism and Job Satisfaction for Policewomen, American Journal of Criminal Justice, Vol.28, No.1, pp.73-88.

Lach, D. H. \& Patricia, A. G. (1993). Sociological Perspectives on Sexual Harassment and Workplace Dispute Resolution, Journal of Vocational Behavior, Vol.42, No.1, pp.102-115.

Lonsway, K. A. \& Alipio, A. M. (2007). Sex Discrimination Lawsuits in Law Enforcement, Women \& Criminal Justice, Vol.18, No.4, pp.63-103.

Lonsway, K. A., Paynich, R. \& Hall, J. N. (2013). Sexual Harassment in Law Enforcement Incidence, Impact and Perception, Police Quarterly, Vol.16, No.2, pp.177-210.

Lutgen-Sandvik, P., Namie, G. \& Namie, R. (2009). Workplace Bullying: Causes, Consequences and Corrections, In: Lutgen-Sandvik, P. \& Sypher, B. D. (2009). Destructive Organizational Communication: Processes, Consequences and Constructive Ways of Organizing, Routledge/Taylor \& Francis, New York, pp.27-52.

Mahalawat, P. \& Rufus, D. (2017). An Analysis of Workplace Environment of Women Police in Jaipur, Rajasthan, In: Janaki, M. C. \& Kumar, A. S. (Eds.), Police In the Contemporary Society, IGGA Publication House, Mysuru, pp.183-244.

Manickavasagam, B. (2016). Women Police Personnel in Tamil Nadu, Third Concept - An International Journal of Ideas, Vol.30, No.354, pp.36-42. 
McLaughlin, H., Uggen, C. \& Blackstone, A. (2012). Sexual Harassment, Workplace Authority, and the Paradox of Power, American Sociological Review, Vol.77, No.4, pp.625-647.

Merkin, R. S. \& Shah, M. K. (2014). The Impact of Sexual Harassment on Job Satisfaction, Turnover Intentions and Absenteeism: Findings from Pakistan Compared to The United States, Springer Plus, Vol.3, No.1, pp.167-192.

Muhlhausen, D. B. (2019). Women In Policing: Breaking Barriers and Blazing a Path, National Institute of Justice Special Report, U.S. Department of Justice Office, Washington D.C., USA, July, pp.1-33.

Pershing, J. L. (2003). Why Women Don't Report Sexual Harassment: A Case Study of an Elite Military Institution, Gender Issues, Vol.21, No.4, pp.3-30.

Science News. (2017). Workplace Sexual Harassment 'A Chronic Problem', $16^{\text {th }}$ November 2017.

Seklecki, R. \& Paynich, R. (2007). A National Survey of Female Police Officers: An Overview of Findings, Police Practice and Research, Vol.8, No.1, pp.17-30.

Shetty, A. \& Nithyashree, B. (2017). Workplace Harassment among Employees: An Explorative Study, Archives of Medicine and Health Sciences, Vol.5, No.2, pp.187-190.

Somvadee, C. \& Morash, M. (2008). Dynamics of Sexual Harassment for Policewomen Working alongside Men, Policing-An International Journal, Vol.31, No.3, pp.485-498.

Steinporsdottir, F. S. \& Petursdottir, G. M. (2018). Preserving Masculine Dominance in the Police Force with Gendered Bullying and Sexual Harassment, Policing-A Journal of Policy \& Practice, Vol.12, No.2, pp.165-176.

Suresh, R., Sridhar, S. \& Kairanna, S. S. (2014). A Systems Approach to Combat Workplace Sexual Harassment, IOSR Journal of Humanities and Social Science, Vol.19, No.10, pp.29-36.

The New Indian Express (2020). Uttar Pradesh Woman Cop Alleges Sexual Harassment By Senior, $9^{\text {th }}$ January 2020.

Trickett, P. K., Noll, J. G. \& Putnam, F. W. (2011). The Impact of Sexual Abuse on Female Development: Lessons from a Multigenerational, Longitudinal Research Study, Development and Psychopathology, Vol.23, No.2, pp.453-476. 
Unnikrishnan, B., Rekha, T., Kumar, G., Reshmi, B., Mithra, P. \& Sanjeev, B. (2010). Harassment among Women at Workplace: A Cross-Sectional Study in Coastal South India, Indian Journal of Community Medicine, Vol.35, No.2, pp.350-352.

Vargas, E. A., Brassel, S. T., Cortina, L. M., Settles, I. H., Johnson, T. R. \& Jagsi, R. (2020). \#MedToo: A Large-Scale Examination of the Incidence and Impact of Sexual Harassment of Physicians and Other Faculty at an Academic Medical Center, Journal of Women's Health, Vol.29, No.1, pp.13-20.

Vasudevan, L. (2018). Tamil Nadu Woman Cop Lodges Sexual Harassment against Top Officer, India Today, $22^{\text {nd }}$ August 2018.

Vijayasiri, G. (2008). Reporting Sexual Harassment: The Importance of Organizational Culture and Trust, Gender Issues, Vol.25, No.1, pp.43-61.

Wilson, A. A. (2016). Female Police Officers' Perceptions and Experiences with Marginalization: A Phenomenological Study, Doctoral Thesis, College of Social and Behavioural Sciences, Walden University, Minneapolis, USA, 132p.

Wright, P. C. \& Bean, S. A. (1993). Sexual Harassment: An Issue of Employee Effectiveness, Journal of Managerial Psychology, Vol.8, No.2, pp.30-36.

\section{Webliography}

https://hbr.org/2016/10/why-we-fail-to-report-sexual-harassment http://legislative.gov.in/sites/default/files/A2013-14.pdf https://pib.gov.in/newsite/PrintRelease.aspx?relid=197734

https://www.cnbctv18.com/views/indias-policewomen-increasingly-feelunsafe-at-the-workplace-5391401.htm

https://www.eeoc.gov/laws/guidance/policy-guidance-current-issues-sexualharassment

https://www.humanrightsinitiative.org/blog/women-in-police-india-needsmore-than-just-political-promises-to-raise-numbers

https://www.indiatoday.in/india/story/tamil-nadu-woman-cop-lodges-sexualharrasment-against-top-officer-1320158-2018-08-22 
Holistic Research Perspectives Vol.5

https://www.ncbi.nlm.nih.gov/pmc/articles/PMC6483172/pdf/pone.0215067.p df

https://www.ncjrs.gov/pdffiles1/nij/252963.pdf

https://www.newindianexpress.com/nation/2020/jan/09/up-woman-copalleges-sexual-harassment-by-senior-probe-on-2087410.html

https://www.sciencedaily.com/releases/2017/11/171116142131.htm

https://www.washingtonpost.com 